\title{
Library and information science practitioners writing for publication: motivations, barriers and supports
}

\author{
Janet Clapton
}

\begin{abstract}
Few research studies have investigated UK LIS practitioners' motivation for publication, the barriers they perceive and which supports they think would help, and there is a particular lack of research on publication by practitioners who do not work in academic libraries. This investigation drew evidence from two sources: a small scale quantitative survey to assess variation in the extent of practitioner publishing in 12 LIS publications, including peer reviewed journals and practitioner magazines; and an online survey of self-perceived motivations, barriers, and writing support wishes, undertaken by 100 LIS practitioners in September 2009.
\end{abstract}

Key motivations included sharing ideas, professional development and raising the personal profile. Lack of time was the most reported barrier to participation, while protected time to write, peer encouragement and organisational support via appraisal objectives were most commonly requested supports. The findings will be of interest to those who wish to participate in or promote LIS practitioner publishing and research.

\section{Introduction}

This introduction describes the context for practitioners' writing and research, including the relationship between writing for publication and practitioner research.

Writing about research is an important part of the research cycle. The nature of this cycle and how practice fits into it has been outlined succinctly by Hall (2009) as:

- Draw on and understand the research context

- Identify a problem or evidence gap

- Make an informed and appropriate choice of research approach

\section{Janet Clapton}

Janet Clapton manages an information specialist team at the Social Care Institute for Excellence. She aims to promote wider participation in research.

Email: janet.clapton@scie.org.uk 
- Carry out research (collect and analyse data)

- Relate findings to research context (thereby improving the evidence base and raising the standard of practice)

Hall (2009) stated the dual importance of published research as directing future effort and adding to research context. However, she also noted that publication is not the only means of research dissemination, other routes including social media and conference presentation.

Not all writing by practitioners is for research dissemination (in the narrowest sense). Other types of writing include commentary, practice descriptions, news items and opinion pieces. Scholarly journals usually include some peer reviewed content. Some journals are more like professional magazines, reporting on practice issues, and most journals include both peer reviewed and non-peer reviewed content. Even allowing for these distinctions, the issue of the status of practitioner research is related to practitioners' publication outputs.

How large is the UK LIS practitioner group? The Chartered Institute of Library and Information Professionals (CILIP) estimate is 36,000 (CILIP, 2009). LISU, the library and information statistics organisation, publish broadly similar statistics for the 2006-7 combined public and academic library workforce (LISU, 2006/7). In a North American study of 612 participants (Powell, Baker et al. 2002) it was estimated that almost $90 \%$ regularly read at least one research journal, $50 \%$ occasionally applied research findings to practice and $42 \%$ occasionally or frequently carried out research. McNicol surveyed $334 \mathrm{UK}$ librarians in different sectors and found that $52 \%$ had been involved in research in the previous two years $(33 \%-67 \%$, depending on sector, with school libraries and academic libraries representing the extremes). Findings from Schlackman's study of 85 academic librarians showed that $82 \%$ had researched as part of their work responsibilities, $58 \%$ had carried out research outside of work responsibilities and $65 \%$ had published (Schlackman, 2009). The majority of this output was internal publication, followed by conference proceedings, case studies and book reviews, followed by research findings, book chapters, blogs and wikis. Schlackman's findings confirmed those of Powell et al. that practitioner research is relatively unlikely to be published externally: Powell et al. (2002) surveyed 571 US LIS practitioners who had carried out research and found that more than half had not published their findings.

Separation between practitioner writing and academic writing has been found in a number of studies. Hildreth and Aytac (2007) surveyed characteristics of 206 articles from 23 LIS journals published between 2003 and 2005. The results of this North American based study included findings such as separation of academic or practitioner author groups. By far the most common research type used was descriptive (77\%) (rather than exploratory, evaluative or explanatory) and descriptive studies were preferred by practitioners compared with academics. Schlogl and Stock (2008) carried out a detailed, multi-method study of the journals which German speaking academics and practitioners chose to read and publish in, the characteristics of these journals and citation analysis of author affiliation in reference lists in published articles. They also concluded that there 
was little cross-over between the two groups. Eve and Schenk, in the Interactions project, described good practice as well as barriers in practitioner / researcher collaboration (Eve and Schenk, 2007). Feather (2009) contrasted practitioner and academic research disciplines within LIS, including their origins in the early to mid $20^{\text {th }}$ century, and reasons for discord between their supporters. However, he maintained belief in the contribution that both could make to develop the LIS field.

The benefits of LIS research in general were identified in the Research Landscape Project as informing practice; planning future developments; raising the profile of the discipline; teaching and course design; raising the profile of services; contributing to knowledge; and individual interest (McNicol and Nankivell, 2002). In 2009, the Southampton Practice Research Initiative Network Group (SPRING) recognized the importance of practice research across practical disciplines with the publication of the Salisbury Statement on Practice Research (SPRING, 2009). Although SPRING has its roots in social work, the statement encompasses the requirement of all practice based professions to increase effectiveness and accountability, be evidence based and carry out good quality research on practice matters. The authors of the statement acknowledge mainstream thinking that research drives practice, but challenge that with explanation of the importance of dialogue between practitioners and researchers with a view to practice questions influencing research (Southampton Practice Research Initiative Network Group, 2009).

Overall, the context is of a large practitioner group, of which a significant proportion carries out research. However, not all of this research is widely disseminated by external publication. Through this study, the aim is to help explain this situation and point to possible solutions by describing LIS practitioners' motivations to publish, perceived barriers and requested supports. Little attention has been paid to this group in previous research on writing for publication.

Assumptions made within the study include the representativeness of the survey respondents. In fact, they were self-selecting members of 6 UK-based LIS jiscmail discussion lists and so were probably particularly interested in writing for publication.

\section{Literature review}

This is a selective review of previous studies findings on motivations for writing, reported barriers and requested supports among LIS practitioners.

\subsection{Motivations for writing}

What motivates practitioners to write for publication? Schlackman surveyed 130 UK academic librarians' motivations to research and publish and found that 'to improve practice in the organisation' was the most popular choice $(33 \%)$ followed by 'personal interest' (Schlackman, 2009). She considered that these findings confirmed other studies such as Powell et al.'s work (2002) in that practitioner researchers are strongly self-motivated and interested in evidence-based practice improvement. The next most popular profiles were to 'raise personal profile', 
'career progression' and to 'raise the library's profile'. Professional development is another key reason (Joint, 2006) and leadership development has also been suggested (Kester, 1997). In the US, publication is expected towards gaining permanent contracts in academic libraries (tenure) (Miller and Benefiel, 1998) but support helps motivate those not in tenured positions (Palmer and Matz, 2006).

Edem and Lawal (1999) focused on the influence of job satisfaction on the publication output of 202 LIS professionals in Nigerian University libraries. The relationship appeared to be complex: satisfaction with achievement, responsibility and recognition appeared to improve the quality of output, whereas salary level, university policies and supervision did not influence output. Financial reward is missing from lists of motivations in other studies (Bradley, 2008). In personal discussion, a colleague mentioned that she found a salary bonus for publication an incentive. Another colleague reflected that this effect could be more about recognition than desire for material gain. This was echoed by the request for an annual prize, made by a participant on Fallon's writing support programme for Irish academic librarians (Fallon, 2009).

\subsection{Barriers}

\subsubsection{Time}

Lack of time is consistently mentioned in the literature as the most significant barrier to practitioners carrying out research, for example in McNicol's cross sector comparison of practitioner research in libraries (McNicol, 2004). Joint, in his editorial on practitioner - researcher collaboration, discussed the impact of research activity on workload. As a plus, he felt that involvement in service evaluation could be a time-saving activity, but noted the time and effort required to prepare or respond to research proposals (Joint, 2005). Boice (1987) specifically compared the pressures on academic library staff matched with academics with respect to writing for publication. He concluded that both groups seemed to have enough time in their schedules, but that practitioners experienced other barriers such as 'unsupportive work cultures' and 'entrenched working habits' which prevented them making use of short slots of free time. Boice reported (in 1987) that this 'free time' seemed to be filled by reading magazines or newspapers. In 2010 it would be filled by answering emails or online social networking!

The premise that regular short bursts of writing can give greater productivity than long sessions underpins subscription support groups such as The Academic Writing Club (2010). Boice was unusual in going beyond the face value of the 'time' excuse, and Schlackman also asked why time was such a problem. In her survey, 'too large a workload', 'impact on work-life balance' and 'no time to reflect' were combined as a time pressure, the greatest barrier, followed by 'not an organizational priority' as the next most important barrier. This suggests that practitioners need permission to carry out research and writing in a feasible timescale. More senior staff seemed to have a greater publication output, but they identified time pressure as being even more significant than did junior staff (Schlackman, 2009). 
Despite these authors' attention, there is a gap in explanatory research on time pressures on practitioner writing.

\subsubsection{Job roles}

Seniority does not necessarily mean that practitioners have more time to publish. As mentioned above (Schlackman, 2009), publication tended to be an activity carried out by senior staff, but they perceived even more time pressure than junior staff. Bradley (2008) studied authorship by new LIS professionals presenting at a new professionals conference in Australia. Although her sample size was small (31) the responses showed that only $6 \%$ were required to publish for their job and stronger motivators were networking, personal development and interest in the specific topics.

\subsubsection{Staff skills, financial resources, relevant topics}

Shenton (2008) mentions issues of support and confidence in his guide to surviving this process. He listed potentially negative experiences once writing is underway, including feeling intimidated by the peer review process, rejection of proposed articles by editors, suppression of negative results, or other events (e.g. workplace reorganisation, personal life events), all of which affect capacity to see the publication process through. Staudt et al.'s study of social work practitioners' barriers to publication (2003) found that after lack of time (55\%) the next most cited barriers were aspects of the review and publication process $(26 \%)$ and lack of experience / skills (13\%). McNicol also cited financial resources, staff skill deficiency and lack of practically focused subjects to research (McNicol 2004).

\subsection{Support for writing}

This section considers specific initiatives planned for practitioners; situations, either experienced or requested, which aided writing for publication; and resources which were found to be supportive.

A few studies have focused specifically on support programmes for practitioners working in academic libraries. Fallon described a formal series of workshops to help Irish academic librarians (Fallon, 2009). Tysick and Babb gave details of an academic writing group to support librarians applying for permanent academic positions (Tysick and Babb, 2006) and Miller and Benefiel described a similar support group (Miller and Benefiel, 1998).

Guidance to writing for publication is relatively abundant in the literature. Several resources have been written specifically for LIS professionals (Bahr and McLane, 1997; Hernon, 2003; Gordon, 2004; Gordon, 2004; Putnam, 2009). These tend to be US-orientated, reflecting requirements to publish to gain permanent academic librarianship posts.

Some of the supports for writing that were reported or requested mirrored the barriers described above. Powell et al. (Powell, Baker et al. 2002) reported positive correlation between conducting research and time to do research during work hours, and with receiving internal and / or external support. Swanepoel (2006) proposed an 'involve as many staff as possible' approach for university 
library research practitioners; this could also be a means of overcoming time allocation, organizational culture and permission barriers.

Overall, the literature gives us a picture of quantitative and qualitative differences between LIS practitioners and academics writing for publication. Little attention has been paid in the past to publication by LIS practitioners who do not work in academic libraries, although there is some literature from comparable professions such as social work. Only one study was found which included non-research writing (Schlackman, 2009).

\section{Methodology}

A mixture of qualitative and quantitative research methods was used, including unstructured discussion with colleagues and an online survey (question styles included fixed choice responses plus text boxes for alternative options and comments). A similar (but more detailed) approach was used by Schlackman in her unpublished MSc dissertation (2009), accessed after completion of experimental work in the present study.

The extent of practitioner publishing in peer reviewed and professional magazines or journals was explored by analysing author affiliations of articles and reports within 12 purposively selected publications (7 journals and 5 magazines). The publications were chosen as representative of publications which a UK-based practitioner might read. Several studies have used variations of the publication author affiliation approach, e.g. (Schlogl and Stock, 2008). In the current study, an article was categorised as practitioner authored if at least one author was not affiliated to an academic institution. This categorisation is simple to apply but has the limitation of discounting practitioners who work in an academic setting, thereby potentially underestimating practitioner authorship. Articles and reports were defined as discrete headed written accounts, with a named author, but editorial was excluded. Simple statistical analysis was used to describe the percentage of articles written by practitioners who were not affiliated to an academic institution.

While this work was underway, initial informal discussion was carried out with four practitioner peers in the author's workplace, to establish qualitative issues. This explored issues such as time available, motivation, concerns, and potential support. Five workplace colleagues then piloted and fed back comments on the online survey, which had been developed from the author's own ideas and their suggestions. Their anonymous feedback guided clarification of the questions for development of the final version of the survey, which contained 9 questions (see Appendix). The survey was publicised on 6 UK-based LIS jiscmail discussion lists: LIS-LINK, LIS-PROFESSION, LIS-LIRG, LIS-CILIP-REVAL, LISRESEARCH-SUPPORT, LIS-UKEIG in September 2009. Survey Monkey Www.surveymonkey.com was used to present the survey; the free option was chosen, which closed on 100 replies after 36 hours. The responses were entered manually into Excel ${ }^{\mathrm{TM}}$ (Microsoft Corporation, 2007) and simple descriptive statistical analysis carried out on quantifiable responses. Sector based contingency tests and calculation of chi-squared values for significant difference have been used in other studies (Powell, Baker et al. 2002; Hildreth and Aytac, 2007), but 
could not be calculated here as the questions offered more than one response. The solution chosen was comparison by order of popularity of response.

Free text comments were coded and analysed in the qualitative data analysis programme QSR N6 TM (QSR International, 2002).

\section{Results}

\subsection{Extent of practitioner authored articles within publications}

Latest issues of the following journals and magazines (as at October 2009) were assessed for author affiliation except where starred, where the most recent issue available in full text was used. The results are shown below:

\begin{tabular}{|c|c|c|}
\hline Publication & $\begin{array}{l}\text { Type of } \\
\text { publication }\end{array}$ & $\begin{array}{l}\text { Percentage } \\
\text { practitioner } \\
\text { authored articles }\end{array}$ \\
\hline Free Pint & $\begin{array}{l}\text { Professional } \\
\text { magazine }\end{array}$ & 100 \\
\hline Managing Information & $\begin{array}{l}\text { Professional } \\
\text { magazine }\end{array}$ & 100 \\
\hline $\begin{array}{l}\text { Career Development } \\
\text { Group 'Impact' }\end{array}$ & $\begin{array}{l}\text { Professional } \\
\text { magazine }\end{array}$ & 100 \\
\hline CILIP 'Update' & $\begin{array}{l}\text { Professional } \\
\text { magazine }\end{array}$ & 67 \\
\hline $\begin{array}{l}\text { Evidence Based Library } \\
\text { and Information } \\
\text { Practice }\end{array}$ & $\begin{array}{l}\text { Peer Reviewed } \\
\text { Journal }\end{array}$ & 62 \\
\hline $\begin{array}{l}\text { Health Information } \\
\text { Libraries Journal }\end{array}$ & $\begin{array}{l}\text { Peer Reviewed } \\
\text { Journal }\end{array}$ & 30 \\
\hline $\begin{array}{l}\text { LIBRI International } \\
\text { Journal of Libraries and } \\
\text { Information Services }\end{array}$ & $\begin{array}{l}\text { Peer Reviewed } \\
\text { Journal }\end{array}$ & 17 \\
\hline $\begin{array}{l}\text { Library and Information } \\
\text { Research }\end{array}$ & $\begin{array}{l}\text { Peer Reviewed } \\
\text { Journal }\end{array}$ & 11 \\
\hline $\begin{array}{l}\text { Journal of Information } \\
\text { Science }\end{array}$ & $\begin{array}{l}\text { Peer Reviewed } \\
\text { Journal }\end{array}$ & 0 \\
\hline $\begin{array}{l}\text { VINE: The journal of } \\
\text { information and } \\
\text { knowledge management } \\
\text { systems }\end{array}$ & $\begin{array}{l}\text { Peer Reviewed } \\
\text { Journal }\end{array}$ & 0 \\
\hline $\begin{array}{l}\text { Library and Information } \\
\text { Research Electronic } \\
\text { Journal* }\end{array}$ & $\begin{array}{l}\text { Peer Reviewed } \\
\text { Journal }\end{array}$ & 0 \\
\hline
\end{tabular}

Table 1: Analysis of representative LIS publications for proportion of practitioner authorship.

Although relatively few publications were investigated, they fall into two groups of high practitioner authorship in professional magazines and low practitioner 
authorship in peer reviewed journals. The extremes are represented by the professional magazines FreePint, Managing Information and the Career Development Group's Impact (100\% practitioner authorship) and the peer reviewed journals Journal of Information Science, VINE: The journal of information and knowledge management systems, and Library and Information Research Electronic Journal (0\% practitioner authorship). The two publications at the interface are CILIP Update, a professional magazine, and Evidence Based Library and Information Practice, a peer reviewed journal, both of which have around two thirds practitioner authorship.

\subsection{Results of online survey of LIS practitioners' perceived motivations, barriers and desired supports for writing for academic or professional publications}

100 responses were collected, including the 5 pilot responses. These were included as question modification was relatively minor between the pilot and final versions of the survey.

$57 \%$ of the respondents worked in an academic library and $43 \%$ did not.

Initially, the two groups' responses were analysed separately, although subsequently the results were combined as responses were so similar, varying by 11 to 16 per cent between the groups (mean difference $0 \%$ ). The only difference in order of response popularity was in the four least popular choices on perceived barriers

Of the combined responses, $76 \%$ of respondents had already written for publication. All 100 respondents were either interested in writing $(81 \%)$ or possibly interested (19\%) (although one later ticked lack of interest as a barrier).

Of the 54 who specified which type of writing they were interested in, nearly half were interested in writing for both professional and peer reviewed publications. Preference for writing for peer review only was more common among academic library practitioners than non-academic library practitioners but the number of responses favouring this option was considered too small to draw firm conclusions (9 as opposed to 4 ).

Responses to motivations, barriers and requested supports are shown in Tables 2-4 and described on the following pages.

\begin{tabular}{|l|l|}
\hline Motivation & $\begin{array}{l}\text { Percentage of respondents } \\
(\mathbf{N}=100) \text { choosing this option }\end{array}$ \\
\hline To share my ideas with others & 84 \\
\hline For professional development & 78 \\
\hline To raise my profile & 47 \\
\hline To publicise my organisation or sector & 47 \\
\hline Approached by an editor & 23 \\
\hline Other & 17 \\
\hline Financial reward & 11 \\
\hline
\end{tabular}

Table 2: Practitioners' stated motivations for writing for publication, in decreasing order of preference. 
When the 'other' comments $(\mathrm{n}=19)$ were analysed and grouped, these included:

- to add to the body of knowledge

- to improve career prospects or as an obligation of a job

- personal development

- social responsibility

- $\quad$ subject enjoyment

\begin{tabular}{|l|l|}
\hline Barrier & $\begin{array}{l}\text { Percentage of respondents } \\
(\mathbf{N}=100) \text { choosing this option }\end{array}$ \\
\hline Lack of time & 80 \\
\hline More skill needed & 30 \\
\hline Lack of confidence & 28 \\
\hline Fear of rejection by editors & 24 \\
\hline Lack of support or example from peers & 19 \\
\hline Other & 16 \\
\hline Employer / manager is not supportive & 11 \\
\hline Not interested & 1 \\
\hline
\end{tabular}

Table 3: Practitioners' stated barriers to writing for publication, in decreasing order of preference.

When the 'other' comments $(\mathrm{n}=20)$ were analysed and grouped, these included:

- expectation, within self or manager / organisation, that academics publish while practitioners should get on with their work.

- related to this, having to rely on own resources due to resistance of employer

- lack of suitable subjects or opinions

- procedural uncertainty

- lack of acceptance within the profession of open access collaboration

\begin{tabular}{|l|l|}
\hline Support & $\begin{array}{l}\text { Relative preference among 99 respondents, } \\
\text { in order of perceived helpfulness } \\
\text { (1=very helpful, 2=moderately helpful, } \\
\mathbf{3 =}=\text { unhelpful) }\end{array}$ \\
\hline Protected time to write & 1.28 \\
\hline Peer encouragement & 1.42 \\
\hline Written into appraisal & 1.68 \\
\hline Online support group & 1.94 \\
\hline Tailored course & 1.97 \\
\hline List of resources & 1.98 \\
\hline Financial reward & 2.09 \\
\hline $\begin{array}{l}\text { Websites listing your } \\
\text { goals publicly }\end{array}$ & 2.47 \\
\hline
\end{tabular}

Table 4: Practitioners' requested supports, in decreasing order of preference. 
When the 'other' comments $(\mathrm{n}=21)$ were analysed and grouped, these included:

- reiterating the time requirement

- online peer support

- guidance and support from editors

- guidance on which publications to target

- a topic or article call

- integration of research ethos into work practice

- having a mentor

Lack of an appraisal plan was noted by one respondent.

\section{Limitations}

This is a relatively small scale piece of work. Given the wish to compare responses from different sectors within the sample, a larger sample size was needed so the decision to use the free version of Survey Monkey (which limited responses to 100) should be reviewed.

Ethical aspects should have been included in the methodology. An explicit statement seeking consent could have enabled direct quotation of respondents' comments, many of which were succinct, insightful and even impassioned. Lack of literature on practitioners writing for publication prompted me to draw on research on the overlapping activity of practitioner research. However, this activity, although related, is not identical to writing for publication.

\section{Discussion}

The 100 participants in the online survey were LIS practitioners. I aimed to focus on those who carry out a practical job within a profession, rather those who are employed as teachers and researchers by academic or research institutions. My initial plan was to differentiate between the views of professionals who work in academic libraries (who may receive support for publication activity) and those who work in other settings. In practice, negligible difference was found between the views of practitioners working within (57/100) or outside academic libraries (43/100) so all 100 responses were aggregated.

The findings largely confirm previous studies' conclusions for motivations, barriers and support for writing by academic library practitioners. The key motivations of sharing results, professional development and publicity for self and organisation broadly repeated other studies' findings, as did relative lack of interest in financial incentives. Time is consistently reported as the greatest barrier, followed by lack of confidence in skills and processes, and this was confirmed in the present study. Time for writing and peer encouragement were the most requested supports. 


\section{Conclusion}

This study shows that the stated motivations, perceived barriers and requested supports were broadly similar for those working in and outside academic libraries. Previous UK research on writing for publication has concentrated on those working in academic libraries.

The findings could be used to promote practitioner writing

- by improving self-awareness and preparing practitioners to face challenges in writing for publication

- by validating and benchmarking practitioners own feelings about their motivations, perceived barriers and requested supports

- $\quad$ as evidence to help negotiate supports within organisations

- for wider advocacy of practitioner writing.

There may be scope to build on intrinsic motivations such as desire for professional recognition, and formal 'permission' from the organisation culture via appraisal objectives. The barriers of lack of time, lack of confidence in skills, and need for peer support could be addressed by formal programmes which involve a significant proportion of the workforce.

The topic is interesting and warrants further research, especially to investigate further the reasons behind perceived time pressure at work.

\section{References}

Bahr, A. H. C. and McLane, M. J. C. (1997) InPrint: publishing opportunities for college librarians. Chicago: Association of College and Research Libraries.

Boice, R. (1987) Librarians and faculty members: coping with pressures to publish. College \& Research Libraries 48, 494-503.

Bradley, F. (2008) Writing for the profession: the experience of new professionals. Library Management 29(8/9), 729-745.

CILIP. (2009) About us. URL: http://www.cilip.org.uk/aboutcilip [accessed 10.10.09].

Edem, U. S. and Lawal, O. O. (1999) Job satisfaction and publication output among librarians in Nigerian universities. Library Management 20(1), 39-46.

Eve, J. and Schenk, N. (2007) Research and practice: findings from the Interactions project. Library \& Information Research 96, 37-47.

Fallon, H. (2009). A writing support programme for Irish academic librarians. Library Review 58(6), 414-422.

Feather, J. (2009) LIS research in the United Kingdom: Reflections and prospects. Journal of Librarianship and Information Science 41(3), 173-181. 
Gordon, R. S. (2004) Getting started in library publication: advice on finding your place in library literature. American Libraries 35(1), 66-69.

Gordon, R. S. (2004) The Librarian's Guide to Writing for Publication. Lanham, Md: Scarecrow Press.

Hall, H. (2009). Introducing the LIS Research Coalition. Online Information, Olympia, London. URL: http://www.slideshare.net/LISResearch/introducing-thelis-research-coalition [accessed 31.01.10].

Hernon, P., Ed. (2003) Peer review. How to Get Published in LIS Journals: A Practical Guide. Pamphlet 2, Elsevier/Library Connect.

Hildreth, C. R. and S. Aytac (2007) Recent library practitioner research : a methodological analysis and critique. Journal of education for library and information science 48(3), 236-258.

Joint, N. (2005) Promoting practitioner-researcher collaboration in library and information science. Library Review 54(5), 289-294.

Joint, N. (2006) Enhancing professional development by writing for publication in library and information science. Library Review (UK) 55(1), 5-8.

Kester, N. G. (1997) Enhancing career and leadership opportunities in LIS through professional communication." Librarian Career Development 5(1), 5-11.

LISU. (2006/7) Libraries, Archives, Museums and Publishing Online Statistics Tables: Number working in libraries. URL:

http://www.lboro.ac.uk/departments/ls/lisu/lampost08/emp08.html\#libemp [accessed 01.01.10].

McNicol, S. (2004) Practitioner research in libraries: a cross-sectoral comparison. Library \& Information Research 28(88), 34-41.

McNicol, S. and Nankivell, C. (2002) The LIS Research Landscape: A Review and Prognosis. Birmingham: Centre for Information Research.

Microsoft Corporation (2007) Excel 2007. Redmond, WA: Microsoft Corporation.

Miller, J. P. and Benefiel, C. R. (1998) Academic librarians and the pursuit of tenure: the support group as a strategy for success. College \& Research Libraries News 59(3), 1-6.

Palmer, P. and Matz, C. (2006) Promoting writing among nontenured faculty. College \& Research Libraries News 67(6), 372-374.

Powell, R. R., Baker, L. M. and Mika, J. (2002) Library and Information Science Practitioners and Research. Library and Information Science Research 24, 49-72.

Putnam, L. L. (2009) Professional writing and publishing: resources for librarians. College \& Research Libraries News 70(4).

QSR International (2002) QSR N6. Doncaster, Victoria: QSR International.

Schlackman, E. (2009) An exploration of the motivations and barriers for UK academic librarians to conduct research. MSc (ILM) dissertation, University of the West of England. 
Schlogl, C. and Stock, W. G. (2008) Practitioners and academics as authors and readers: the case of LIS journals. Journal of Documentation 64(5), 643-666.

Shenton, A. K. (2008) The frustrations of writing research articles for publication and what to do about them. Library and Information Research 32(101).

Southampton Practice Research Initiative Network Group. (2009) The Salisbury Statement on Practice Research URL:

http://www.socsci.soton.ac.uk/spring/salisbury/The_Salisbury_Statement_on_prac tice research May 2009.pdf [accessed 24 December 2009].

SPRING. (2009) Salisbury Statement on Practice Research URL:

http://www.socsci.soton.ac.uk/spring/salisbury/The_Salisbury_Statement_on_prac tice_research_May_2009.pdf [accessed 01.01.10].

Staudt, M. M., Dulmus, C. et al. (2003) Facilitating writing by practitioners: Survey of practitioners who have published. Social Work 48(1), 75-83.

Swanepoel, A. (2006) Involving university library staff in ongoing research. IATUL Annual Conference Proceedings 16, 78-82.

The Academic Writing Club. (2010). The Academic Writing Club. URL: http://academicwritingclub.com/ [accessed 10.01.10].

Tysick, C. and Babb, N. (2006) Perspectives on writing support for junior faculty librarians: a case study. Journal of Academic Librarianship 32(1), 94-100.

\section{Acknowledgement}

Thank you to my colleagues at the Social Care Institute for Excellence and at Cafcass (Children and Family Court Advisory and Support Service) for their helpful input. I am also grateful to Elizabeth Schlackman for sharing her dissertation with me.

\section{Open access and copyright}

Library and Information Research is an open access journal. A freely available copy of this paper may be downloaded from the journal's website:

http://www.cilipjournals.org.uk/lir

Copyright and associated moral rights in works published in Library and Information Research are retained by the author(s) but this paper may be used freely, with proper attribution, in educational and other non-commercial settings. 


\section{Appendix 1}

Below is a transcript of the survey posted online at http://www.surveymonkey.com/s.aspx?sm=budG_2bTzSM3ayB8XwIf07BA_3d $\underline{3 \mathrm{~d}}$

Writing for publication: exploring motivations, barriers and support for LIS practitioners

Research by Library and Information Science practitioners is important because it builds an evidence base for decisions we take during our work. However, few of us carry out research and get it published.

Your help will be much appreciated to examine what motives and barriers exist, and consider what kind of support is needed to encourage professional and academic publishing by LIS practitioners.

Thank you for participating in this short questionnaire.

1. Do you work for a higher education institution?

Yes $\quad$ No

2. Have you ever written for publication, either in professional magazines or peer reviewed journals?

Yes No

3. Would you be interested in writing for these kinds of publication in the future?
Yes
No
Maybe

4. Please explain below if you prefer writing for one publication type to another, e.g. would write for professional press (e.g. CILIP Update) but not peer reviewed journal.

5. If you are interested in writing for publication, what motivates you? (click as many as apply)

To share my ideas with others

To raise my profile

To publicise my organisation or sector

For professional development

Because an editor approached me to write

For financial reward

Other (please enter details in text box below) 
6. If other, please enter details:

7. Tick any of the following that hold you back from writing (click as many as apply)

Not interested

Lack of time

Employer / manager is not supportive

I don't feel confident to write

More skill would be needed, e.g. in data analysis

Lack of support or example from peers

Fear of rejection by editors

Other (please enter details in text box below)

8. If other, please enter details:

9. How helpful would you find the following types of support?

\begin{tabular}{|l|l|l|l|}
\hline & Very helpful & $\begin{array}{l}\text { Moderately } \\
\text { helpful }\end{array}$ & Not helpful \\
\hline $\begin{array}{l}\text { Peer encouragement } \\
\text { at work }\end{array}$ & & & \\
\hline $\begin{array}{l}\text { Protected work time } \\
\text { to write }\end{array}$ & & & \\
\hline $\begin{array}{l}\text { Having it written } \\
\text { into your appraisal } \\
\text { plan }\end{array}$ & & & \\
\hline A tailored course & & & \\
\hline $\begin{array}{l}\text { Websites for listing } \\
\text { your own goals } \\
\text { publicly }\end{array}$ & & & \\
\hline $\begin{array}{l}\text { An online support } \\
\text { group }\end{array}$ & & & \\
\hline List of resources & & & \\
\hline Financial reward & & & \\
\hline
\end{tabular}

Any other support suggestions? 